\title{
Why is the Tradition of Youth Married Sustained in the Madura Region?
}

\author{
Agoes Dariyo $^{1 *}$ Mia Hadiati $^{2}$ R. Rahaditya ${ }^{2}$ \\ ${ }^{1}$ Faculty of Psychology, Tarumanagara University, Jakarta, Indonesia \\ ${ }^{2}$ Faculty of Law, Tarumanagara University, Jakarta, Indonesia \\ "Coresponding author.Email: agoesd@fpsi.untar.ac.id
}

\begin{abstract}
This study seeks to understand the phenomenon of young marriage which has become a tradition on the island of Madura. This research is qualitative in nature by collecting data through in-depth interviews (depth interview). The number of research subjects as many as 6 people who live in Pamekasan, Sampang and Sumenep, Madura. Data analysis used a thematic approach according to the title of this paper. The results showed that young Madurese marriages were caused by matchmaking factors or their own choices, avoiding or preventing adultery, responsible readiness, coming from the village, low levels of education, parental financial inability. Furthermore, all of them are discussed in this article.
\end{abstract}

\section{Keywords: Tradition, young marriage, Madura}

\section{INTRODUCTION}

The general rule stipulated by Law No.1 of 1974 concerning marriage states that the minimum age of marriage is 19 years. Both men and women are the same, still 19 years old. This provision came into effect in 2019, after the DPR RI (People's Representative Council of the Republic of Indonesia) approved (passed) the draft amendment to law number 1 of 1974 concerning marriage. Although the minimum age for marriage in accordance with Law Number 1 of 1974 is 19 years, there are still many people who ignore this law so that some of them get married before the age of 19 [3]. This has been done in various regions of Indonesia (Madura, Rembang, Indramayu) $[4,11,12,13]$, as a result Indonesia is facing a high increase in the rate of early marriage [18].

Meanwhile, early marriage is the trigger and trigger for the high divorce rate in Indonesia (Central Statistics Agency, 2017). Because those who are married at a young age, it turns out that they are not emotionally mature, thus spurring domestic conflicts that end in divorce [4].

One of the contributors to the high divorce rate in the province of East Java is the high divorce experienced by those who undergo early marriage [7]. One of the regions of East Java province that has a fairly high rate of early marriage is Madura $[7,11,12,13]$. However, they did not mention the number of divorce rates experienced by the Madurese. Madura is an island separate from the island of Java, but Madura is still an important part of the province of East Java. From generation to generation, early marriage has become a tradition carried out by previous generations to the present generation. For hundreds of years, people have been living or undergoing early marriage $[11,12,13]$.
However, early marriage remains an effective solution to dealing with adultery among young people [1,2,5]. Adultery is an act that is strictly prohibited by religious teachings. Instead of committing adultery, people think that getting married at a young age is the right decision. So where did it go wrong, if indeed the people wanted and carried out the tradition of marrying at a young age. If many young people commit adultery, who will dare to be responsible. Of course no one dared to take responsibility for this incident. Therefore, marrying at a young age is a solution / way to overcome or prevent adultery in society $[1,2]$.

Youth is a period of transition or transition from childhood to adulthood marked by physiological maturity (biological, sexual hormones) [14]. As teenagers, they have a sexual urge to be channeled positively through a marriage that is approved by religion. If they are not (not) married, even though their sex drive is high, then they can channel sexual relations before (outside of marriage), as a result their sexual behavior is considered adultery. This clearly violates religious norms (teachings). On the basis of these various views, the problem formulation in this paper is why is the tradition of young marriage being maintained in the Madura region?

\section{METHOD}

This research is a qualitative research which seeks to understand the phenomenon of the tradition of young marriage in the Madura region. The criteria for research subjects were people who were married at a young age under the age of 19, coming from the Madura tribe. They come from villages in Bangkalan, Pamekasan, Sumenep district. 
Data collection techniques using in-depth interviews (depth interview). Interviews were conducted on the basis of an interview guide that had been prepared in advance.
The data analysis is based on thematic according to the title or research topic.

Table. 1 Subject Description

\begin{tabular}{lllllll}
\hline No & Subject & Age & $\begin{array}{l}\text { Married } \\
\text { age }\end{array}$ & Sex & Education & Job \\
\hline 1 & B & 37 & 17 & M & Elementary & Woodworker \\
2 & ID & 75 & 16 & F & Elementary & Housewife \\
3 & A & 48 & 18 & M & Elementary & Seller of satay \\
4 & T & 17 & 17 & F & High School & Housewife \\
5 & Je & 58 & 12 & F & Elementary & Housewife \\
6 & M & 18 & 18 & F & High School & Housewife \\
\hline
\end{tabular}

\section{Subject B}

B is a 38 year old boy. He works as a carpenter who has been in business for about 21 years. He has long migrated to various regions, namely Lumajang (East Java), Malaysia, and is now in Jakarta. He never graduated from elementary school, even he was unable to read and write. Because at the age of 9 , he is no longer in school.

He married at the age of 17 to a woman the same age as him. The result of this marriage, now he has 3 children. The first child has entered the SMK education level, the second child is still in grade 4 of elementary school (10 years) and the third child is still 2 years old.

\section{Subject ID}

The ID subject is a housewife. ID never graduated from elementary school. When he was still in the 5th grade of SD, ID had been proposed and married to a man who asked him to marry. After giving birth to a child, her husband passed away. Likewise, the child who was born died. At the age of 16 years, ID has the status of a widow. But not long after, she was proposed by $\mathrm{D}$, her husband, who has been accompanying her until now. Marriage with D was held in 1964.

The result of marriage with D, ID has been blessed with 3 sons, namely the first child (born 66 years), the second child (born 69) and the third child (born 1972).

\section{Subject A}

Subject A is a 48 year old male from a village in Pamekasan district, Madura. Subject A only has elementary school education. Furthermore, after graduating from elementary school, he worked for 5-6 years and got married at the age of 18 . The first marriage ended in divorce. From the first marriage, 2 children were obtained. Both are adults, even have families. Now, at the age of 48 years, subject A remarried an 18 year old virgin. This second marriage has not produced offspring.

\section{Subject T}

Subject $\mathrm{T}$ is the second child of 3 siblings in a simple family. Both parents work as traders on a tourist beach. Her brother has migrated and worked in Saudi Arabia. His younger brother is still in junior high school. Subject T is a girl who has married a boy (Ahm, 21 years). He married at the age of 17.

She is married to Ahm, a man who has been dating for 1 year. He started dating during the 11th grade of high school. A year later, when he graduated from school, he immediately married. Actually, her parents wanted to match $\mathrm{T}$ with a man who was economically able, but $\mathrm{T}$ refused and married Ahm, a man of her own choice.

\section{Subject Je}

Je only has elementary school education. Subsequently, Je married at 12 years old, but at 16 years old Je became a widow because Je divorced her husband. Likewise, Je remarried, but divorced again from her second husband. This also happened to the third husband. However, Je married the fourth and her husband passed away. So, now Je is a widow with 4 children.

\section{Subject M}

Subject $M$ is a girl who has just graduated from high school at the age of 18 , then she immediately married $\mathrm{P}$, a 20 year-old young man. Previously, $\mathrm{M}$ was dating $\mathrm{P}$ for 1 year. Subject $M$ chose $P$ because $P$ had worked independently and was able to be responsible if he lived a married life. Based on these considerations, $\mathrm{M}$ agreed to marry $\mathrm{P}$ immediately after graduating from high school. Meanwhile, both parents could do nothing, except to approve (bless) $\mathrm{M}$ to live a domestic life because $\mathbf{M}$ had chosen her own husband. Parents have also seen for themselves how responsible they are. The future husband for his child, M. The prospective husband has become independent by opening a trading business that can fulfill his daily needs. Because of that, M's parents felt sure that $\mathrm{P}$ was the right man for their child.

\section{RESULTS}

From the results of in-depth interviews with the subjects (B, ID, A, T, Je and M), several important points were found related to their reasons for marriage at a young age, including: matchmaking or choice, avoiding adultery, being responsible, financial inability parents. 
Matchmaking or own-choice

Some of the subjects (subject B, ID, A) were married at a young age because they were arranged by their parents. Fellow male parents and female parents met to agree to discuss the arranged marriage of their children. Usually they emphasize the importance of strengthening the brotherhood that still has family ties.

Thus the expression B, namely:

"Yes, I was arranged by my parents. As a child, I just obeyed what my parents said. When my parents arranged for me, then I just obeyed. Everything is for my good. Also kindness of parents. "

Meanwhile, the subjects T, Je and M married on their own choice, not on parental matchmaking. They met a man who loved and proposed to her. Even though parents try to matchmaking, they refuse and choose a man according to their choice of heart. Specifically, M's parents were not matchmaking, because $\mathrm{M}$ had indeed chosen and agreed to M.

\section{Avoiding adultery}

All subjects (B, ID, A, T, Je and M) realized that they married immediately in order to avoid adultery. Dating is fine, but the time of dating should be limited so as not to go too far in the act of adultery. They believe that religious teachings are the best foundation in daily behavior, including how to live a married life. When they were teenagers, they already had a boyfriend, but there was no marriage bond. They realize that they have to undergo a wedding procession, before carrying out their duties as husband and wife.

"My parents and I have the same thoughts. Getting married is better than committing adultery while dating. Because of that, we got married right away, rather than putting off marriage. Religious teachings emphasize avoiding adultery, but allowing marriage when puberty. So there's nothing wrong with getting married immediately. "

\section{Responsibility readiness}

Three subjects (B, A and $\mathrm{M}$ ) felt ready to take responsibility as adults. Whatever they decide, they are ready to take whatever risk they accept. When they decide to get married at a young age, they are ready to accept and undergo the decision to marry at a young age. That is the phrase B, namely: "I am married. I am ready to take responsibility. If I get married, that means I am ready to take responsibility. I do whatever I do, for the sake of providing for my wife and children."

What B said was also agreed upon by A. In principle A agrees with $B$ that marriage is the right way to be responsible in building a family. Getting married is an honorable way to live life as a husband or wife.

Meanwhile, ID subjects, $\mathrm{T}$ and Je are in charge of being a wife. If her husband works outside the home, they are ready to become housewives. They try to keep up with their husbands. They got married knowing that they were ready to become a wife and a housewife.

\section{Come from a village environment and have low or middle education}

The results of this study found that all subjects (B, ID, A, $\mathrm{T}$, Je and M) came from the village. They understand that they are not city people, meaning that they get limited educational opportunities by their parents. This is related to the socioeconomic status of their parents who are classified as poor (modest). Parents are not financially able to pay for their education.

Meanwhile, 3 subjects (B, ID and A) had low education, namely elementary school; while the other 3 subjects $(\mathrm{T}$, Je and M) have senior secondary education (Senior High School). This means that those with low education are the older generation, while those with upper secondary education are the younger generation. This shows a change in the level of education from the older generation to the younger generation.

Table 2 The findings of the factors causing marriage at a young age

\begin{tabular}{llllllll}
\hline No & Subject & Matchmaking & $\begin{array}{l}\text { Self- } \\
\text { choice }\end{array}$ & $\begin{array}{l}\text { Prevent } \\
\text { adultery }\end{array}$ & $\begin{array}{l}\text { Ready of } \\
\text { responsilibity }\end{array}$ & From & Education \\
\hline 1 & B & V & X & V & V & Village & Low \\
2 & ID & V & X & V & V & Village & Low \\
3 & A & V & X & V & V & Village & Low \\
4 & T & X & V & V & V & Village & Middle \\
5 & Je & X & V & V & V & Village & Low \\
6 & M & X & V & V & V & Village & Middle \\
\hline
\end{tabular}

The results of this study found that there were 4 factors that influenced the Madurese community to marry at an early age, including: matchmaking or choice, avoiding adultery, readiness to take responsibility, and low levels of education. Some of the results of this study also support the results of previous studies $[11,12,13]$

Matchmaking factor. Matchmaking apparently has become a tradition carried out by Madurese parents. Parents meet other parents and they have agreed to match their children since childhood $[6,11,12,13]$. Furthermore, they immediately looked for the right time to marry off their children. Children also have to obey the wishes (will) of their parents. This means that parents "force their will" on their children. There was forced marriage between young children by parents [12,13]. When fellow parents have agreed to match their children, they are committed to 
fulfilling the agreement. What is important, they have shown a commitment to matchmaking. Furthermore, after the children have been married, it is all up to them how to form and maintain their families, or even divorce in the middle of the road during marriage. Parents no longer interfere in their affairs [4].

With this custom of matchmaking, the Madurese community has emerged the tradition of early marriage. They as parents try to prevent adultery which is usually committed by people during adolescence. Therefore, they allow their children to marry at a young age, rather than committing adultery when dating $[5,11]$. It is known that the majority of Madurese are Muslim. They really uphold religious teachings. Therefore, they are committed to preventing adultery $[1,2]$, the way parents try to allow their children to marry at a young age, $[11,12,13]$. This is also closely related to the teaching of the religious scholars who emphasize the importance of obeying religious teachings for each of their followers so as not to commit adultery [15].

The traditional factor is carried out by the village community. The villagers in Madura have a tradition that has been going on for generations about getting married at a young age. What has become the tradition (habit) of the ancestors has become a kind of mandatory rule carried out by the next generation. Parents who believe in tradition will follow (obey) the "unwritten" rules that live in society [6]. They will feel guilty, if they break these rules. Therefore, parents are willing and agreeing if their children get married at a young age (teenagers). Both parents matchmaking their children and parents agree on the choice of a potential partner that their child chooses. Those who choose their own partner because it is based on love [15].

The low education factor triggers young people to get married soon, because they do not have meaningful activities in their lives. The results of this study support previous research $[6,11,12,13,17]$ which states that most of those who get married at an early age are those who come from a group of people with low education at the SD level (School Basic). They have no other choice but to work and get married. They have no activity whatsoever. Because of this, they immediately married and took care of their family. Meanwhile, according to Hidayati those with secondary education, or even higher education have the opportunity to delay early marriage, because they focus on learning and achieving their goals [7].

This study found that the factor of low economic ability causes parents to be unable to pay for their children's education, so they choose to immediately marry (marry off) their children. Education as an investment in the future for children. Therefore, sending children to college requires high costs. If parents are not well off financially, then parents may not be able to pay for the highest education possible. Therefore, the cost of children's education is considered an economic burden that must be borne by parents [9].

Therefore, it is in line with the results of research by experts $[6,11,12,13]$ that economic factors are a factor affecting parents in deciding to support marriage for their children. From the point of view of the children, it was also found that they wanted to find a partner with an established economic status. By getting a partner who is economically stable, a person will be guaranteed his future life. In this case, the Madurese people prioritize economic value in building households. Marriage happiness needs to be supported by meeting the economic needs of the family. How can a family be happy if it is not accompanied by economic adequacy? Therefore, it is important for the Madurese community to pay attention to potential partners who have an economically stable family background.

This study found that young marriage is a way to prevent adultery. The results of this study are in line with the research of Sa'dan (2015) and Sari (2016). Early marriage is considered a practical solution faced by the Madurese community $[11,12,13]$. They believe that marriage at a young age is the best solution to prevent adultery among young people who are dating. If they are still dating, it is feared that they are unable to control themselves, as a result they have sexual relations before marriage. In fact, adultery clearly destroys the social norms of society which strictly adhere to religious teachings. Because most of the Madurese people adhere to Islam. So society chooses to immediately marry off their children if they appear to be dating someone who is considered a suitable life partner. Parents immediately agreed (allowed, blessed) their children to marry only, in order to avoid adultery.

Sometimes, parents feel "cheated" by the behavior of their children who are dating. It turns out that their children who are already in their teens have had sexual relations and as a result experience pregnancy before marriage Raharjo, et al [16]. This situation forces parents to immediately marry their children, even though they are still students in middle school (SMP or SMA) [18]. There is no other choice for parents, except to bless the relationship of their children who are dating and marry them as soon as possible, before they give birth to the baby.

\section{CONCLUSION}

On the basis of the findings and discussion of the above research, it can be concluded that there are 4 factors that influence the Madurese community to conduct early marriage, including: matchmaking factors or their own choice, avoiding adultery, readiness to take responsibility, and low levels of education.

\section{ACKNOWLEDGMENT}

A big thank you goes to the Ministry of Education and Culture of the Republic of Indonesia (SP DIPA - 042.06.1.1401516 / 2019) and the Tarumanagara University Research and Community Service Institute (SPK No.1090-SPKKLPPM / UNTAR / VII / 2020) who have supported funds to facilitate this research. 


\section{REFERENCES}

[1] Adhim, M. F. (2003). Indahnya perkawinan dini. Jakarta: Gema Insani Press.

[2] Al Ghifani, A. (2004), Pernikahan dini dilema generasi extravaganza. Jakarta: Mujahidin.

[3] Azizah, N(2018). The analisis of minimum marriage age determinan in Indonesia and other Islamic countries. Jurnal Al-syariah , 16 (2), 148-160.

[4] Benedicta, G.D. (2017). A qualitative study on the causes and consequences of divorce after child married in Sukabumi, Rembang and West Lombok Regencies. Jakarta: Pusat Kajian Gender \& Seksualitas Fakultas Ilmu Sosial dan Ilmu Politik.

[5] Djubaedah, N. (2019). Child marriage and zina in Indonesian Legislation in Islamic Law. Jurnal Hukum \& Pembangunan, 49 (1), 202-223.

[6] Fitrianingsih, R. (2015). Faktor-faktor penyebab pernikahan usia muda perempuan desa Sumberdanti kecamatan Sukowono di Jember. Skripsi. Jember: Fakultas Keguruan dan Ilmu Pendidikan Universitas Jember.

[7] Hidayati, T. (2018). Lima strategi perlawanan perempuan terhadap perkawinan usia dini. https://theconversation.com/lima-strategi-perlawananperempuan-madura-terhadap-perkawinan-dini-96468 diunduh 15 Nov 2020.

[8] Kefalas, M.K., Fursternberg, F.F., Carr, P.J., \& Napotilano, L. (2011). Married is more than together: The meaning of married for young adulths. Journal of Family Issues, 32 (7), 845-875.

[9] Mathur, S., Greene, M., \& Malhotra, A. (2018). Too young too wed: The live, rigths and health of young married girls. ICRW-International Centered for Research on Woman.

[10] Raharjo, W., Citra, A.F., Saputra, M., Damariyanti, T., Ayuningsih, A.M., \& Sihayai, M.M. (2017). Perilaku sex pranikah pada mahasiswa: Jurnal Psikologi, 44 (2), 139-154.

[11] Sari, T. N. I. (2016). Fenomena perkawinan usia dini di Madura. Skripsi. Jakarta: UIN Syarif Hidayatuilah.

[12] Sa'dan, M. (2015a). Menakar tradisi kawin paksa di Madura dengan barometer HAM. Musawa, 14 (2), 143-155.
[13] Sa'dan, M. (2015b). Tradition of forced marriage in Madura: A perspective of sociolegal feminism. Jurnal Perempuan, 20 (1) DOI:http://dx.doi.org/10.34309/jp.42101/52.

[14] Santrock, J. W. (2017). Adolescence. Boston: McGraw-Hill.

[15] Surijah, E.A., Sabhariyanti, N.K.P.D., \& Supriadi. (2019). Apakah ekspresi cinta memprediksi perasaan dicintai ? . Psympantic, Jurnal Ilmiah Psikologi, 6 (1), $1-14$.

[16] Utami, F.T. (2015). Penyesuaian diri remaja putri yang menikah muda. Psikis: Jurnal Psikologi Islami, 1 (1), 11-21.

[17] Qibtiyah, M. (2014). Faktor yang mempengaruhi perkawinan usia muda. Jurnal Biometrika dan Kependudukan, 3 (1), 50-58.

[18] Widyawati, E \& Pierewan, A.C. (2018). Determinan perkawinan usia dini di Indonesia. Jurnal Ilmu-ilmu sosial, 14 (4), 55-70. 